\title{
MOŻLIWOŚĆ UPRAWIANIA TURYSTYKI WODNEJ NA GRANICZNYCH WODACH ŚRÓDLĄDOWYCH I OBSZARACH MORSKICH Rzeczypospolitej POLSKIEJ W ŚWIETLE PRZEPISÓW PRAWA
}

\section{Wstęp}

Wody powierzchniowe są szczególnie cennym walorem rekreacyjnym. Turystyka wodna umożliwiająca bezpośredni kontakt z siłami natury, takimi jak woda i wiatr, po długich latach zastoju zaczęła się prężnie rozwijać, co jest związane przede wszystkim ze zmianą stylu życia społeczeństwa i preferencji w zakresie form uprawianej turystyki ${ }^{1}$.

* Dr hab., prof. Katolickiego Uniwersytetu Lubelskiego Jana Pawła II; e-mail: leszek. cwikla@kul.pl, https:// orcid.org/0000-0002-4048-6653.

1 Pod pojęciem „turystyka wodna” kryje się wiele form spędzania czasu wolnego w sposób aktywny, takich jak kajakarstwo klasyczne (nizinne), kajakarstwo górskie, kajakarstwo morskie (żeglarstwo kajakowe), żeglarstwo śródlądowe (rzeczne lub jeziorowe), żeglarstwo morskie, żeglarstwo deskowe śródlądowe, żeglarstwo deskowe morskie, coraz częściej zwane windsurfingiem (gdy deska wyposażona jest w żagiel; w przypadku kitesurfingu deska napędzana jest rodzajem latawca-paralotni, w przypadku bodyboardingu ślizg na desce odbywa się w pozycji leżącej), żeglarstwo lodowe (bojery), wioślarstwo turystyczne, narciarstwo wodne, wakeboarding. Częścią turystyki wodnej jest turystyka motorowodna - śródlądowa i morska (turystyka motorowodna jest uprawiana na łodziach z silnikami mechanicznymi będącymi główną siłą napędową oraz na kajakach, łodziach wiosłowych i żaglowych, w których silnik stanowi napęd pomocniczy). Rośnie również zainteresowanie bargingiem, który polega na podróżowaniu barkami turystycznymi, będącymi rodzajem płaskodennych jachtów motorowych, coraz więcej zwolenników zyskuje także rafting oraz canoe-kiting, zob. J. Merski, J. Warecka, Turystyka kwalifikowana, turystyka aktywna, Warszawa 2009, s. 222, 244-245. W ustawodawstwie 
W Polsce obowiązuje zasada powszechnego korzystania z wód². Odnosi się ona do korzystania ze śródlądowych powierzchniowych wód publicznych, tj. wód stanowiących własność Skarbu Państwa lub jednostek samorządu terytorialnego, morskich wód wewnętrznych wraz z morskimi wodami wewnętrznymi Zatoki Gdańskiej oraz wód morza terytorialnego. Możliwe jest również powszechne korzystanie $\mathrm{z}$ wód niepublicznych, ale za zgodą właściciela. Zakres powszechnego korzystania z wód obejmuje m.in. wypoczynek oraz uprawianie turystyki wodnej.

Wody graniczne to wody, którymi przebiega granica państwa lub wody w tych miejscach, w których są one przecięte granicą państwa ${ }^{3}$. Linię granicy $w$ miejscach, $w$ których granica państwowa przecina wody stojące lub wody płynące, przechodząc na drugi brzeg, ustala się według linii prostej, biegnącej od jednego znaku granicznego do drugiego, na rzekach, potokach, strumieniach, kanałach nieżeglownych - według linii środkowej koryta, zaś na rzekach żeglownych - według linii środkowej głównego toru wodnego lub linii środkowej głównego nurtu. Wyspy na rzekach granicznych należą do terytorium danego państwa w zależności od linii granicznej ${ }^{4}$.

Polskimi obszarami morskimi są morskie wody wewnętrzne, morze terytorialne, strefa przyległa oraz wyłączna strefa ekonomiczna, przy czym w skład terytorium Rzeczypospolitej Polskiej wchodzą morskie wody wewnętrzne i morze terytorialne. Granica morska przebiega w odległości 12 mil morskich (22 $224 \mathrm{~m}$ ) liczonych od linii podstawowej morza lub po zewnętrznej granicy red włączonych do morza terytorialnego ${ }^{5}$, jej długość wynosi 439,74 km, w tym 22,22 km z Republiką Federalną

istnieje pewien chaos terminologiczny - w niektórych aktach prawnych zamiast pojęcia „turystyka wodna” zostało użyte pojęcie „sporty wodne”.

2 Zob. art. 32 ustawy z dnia 20 lipca 2017 r. - Prawo wodne, tekst jednolity: Dz. U. z 2020 r. poz. 310.

3 Zob. art. 16 pkt 67 ustawy Prawo wodne. W art. 5 ust. 2 ustawy z dnia 12 października 1990 r. o ochronie granicy państwowej (tekst jednolity: Dz. U. z 2019 r. poz. 1776) ustawodawca doprecyzowuje, że pojęcie „wody graniczne” obejmuje rzeki, kanały oraz śródlądowe wody stojące, przez które przebiega granica państwowa.

4 Zob. art. 5 ust. 1 ustawy o ochronie granicy państwowej.

5 Zob. art. 3 ustawy o ochronie granicy państwowej oraz art. 4 i 5 ustawy z dnia 21 marca 1991 r. o obszarach morskich Rzeczypospolitej Polskiej i administracji morskiej, tekst jednolity: Dz. U. z 2019 r. poz. 2169. 
Niemiec, 395,31 km z morzem pełnym (wyłączną strefą ekonomiczną) i 22,21 km z Federacją Rosyjską .

Turystykę wodną można uprawiać na danym obszarze wodnym pod warunkiem przestrzegania obowiązujących na nim przepisów. Dla śródlądowych dróg wodnych są one zawarte w rozporządzeniu Ministra Infrastruktury z dnia 28 kwietnia 2003 r. ${ }^{7}$ oraz w zarządzeniach dyrektorów urzędów żeglugi śródlądowej ${ }^{8}$, zaś dla wód morskich w przepisach porządkowych wydawanych $\mathrm{w}$ formie zarządzeń porządkowych przez dyrektorów urzędów morskich ${ }^{9}$ oraz $\mathrm{w}$ przepisach portowych wyda-

6 https://www.strazgraniczna.pl/pl/granica/granice-rp/1910,Granice-RP.html [dostęp: 15.09.2019 r.].

Zob. rozporządzenie Ministra Infrastruktury z dnia 28 kwietnia 2003 r. w sprawie przepisów żeglugowych na śródlądowych drogach wodnych, Dz. U. z 2003 r. Nr 212, poz. 2072.

8 Zob. zarządzenie Dyrektora Urzędu Żeglugi Śródlądowej w Szczecinie z dnia 7 czerwca 2004 r. w sprawie przepisów prawa miejscowego na śódlądowych drogach wodnych, Dz. Urz. Woj. Zachodniopomorskiego z 2004 r. Nr 41, poz. 785, Dz. Urz. Woj. Lubuskiego z 2004 r. Nr 44, poz. 793; zarządzenie Dyrektora Urzędu Żeglugi Śródlądowej w Kędzierzynie-Koźlu z dnia 17 września 2004 r. w sprawie szczegółowych warunków bezpieczeństwa ruchu i postoju statków na śródlądowych drogach wodnych, Dz. Urz. Woj. Opolskiego z 2004 r. Nr 75, poz. 1967, Dz. Urz. Woj. Śląskiego z 2004 r. Nr 97, poz. 2773; zarządzenie Dyrektora Urzędu Żeglugi Śródlądowej w Giżycku z dnia 25 kwietnia 2006 r. w sprawie szczegółowych warunków bezpieczeństwa ruchu i postoju statków na śródlądowych drogach wodnych, Dz. Urz. Woj. Warmińsko-Mazurskiego z 2006 r. Nr 58, poz. 1107, Dz. Urz. Woj. Podlaskiego z 2006 r. Nr 128, poz. 1228; zarządzenie Dyrektora Urzędu Żeglugi Śródlądowej w Gdańsku z dnia 13 marca 2007 r. w sprawie szczegółowych warunków bezpieczeństwa ruchu i postoju statków na śródlądowych drogach wodnych, Dz. Urz. Woj. Pomorskiego z 2007 r. Nr 84, poz. 1300; zarządzenie Dyrektora Urzędu Żeglugi Śródlądowej w Warszawie z dnia 7 kwietnia 2008 r. w sprawie szczegółowych warunków bezpieczeństwa ruchu i postoju statków na śródlądowych drogach wodnych, Dz. Urz. Woj. Mazowieckiego z 2008 r. Nr 117, poz. 4191, Dz. Urz. Woj. Łódzkiego z 2008 r. Nr 135, poz. 1334, Dz. Urz. Woj. Podlaskiego z 2008 r. Nr 103, poz. 1050, Dz. Urz. Woj. Kujawsko-Pomorskiego z 2008 r. Nr 65, poz. 1103, Dz. Urz. Woj. Lubelskiego z 2008 r. Nr 60, poz. 1774; zarządzenie Nr 1/2015 Dyrektora Urzędu Żeglugi Śródlądowej we Wrocławiu z dnia 25 marca 2015 r. w sprawie szczegółowych warunków bezpieczeństwa ruchu i postoju statków na śródlądowych drogach wodnych, Dz. Urz. Woj. Dolnośląskiego z 2015 r. poz. 2599, Dz. Urz. Woj. Opolskiego z 2015 r. poz. 1417, Dz. Urz. Woj. Lubuskiego z 2015 r. poz. 1057.

9 Zob. zarządzenie porządkowe Nr 10 Dyrektora Urzędu Morskiego w Gdyni z dnia 23 maja 2006 r. w sprawie zapewnienia bezpieczeństwa osób pływających, kąpiących się oraz uprawiających sporty wodne, Dz. Urz. Woj. Pomorskiego z 2006 r. Nr 62, poz. 1278; 
wanych również przez dyrektorów urzędów morskich w formie zarządzeń $^{10}$.

Jednak nie na wszystkich obszarach wodnych, nawet jeśli są obszarami atrakcyjnymi turystycznie, turystyka wodna może być uprawiana, mogą też występować istotne ograniczenia w możliwości jej uprawiania. Można wskazać bardzo różne przyczyny tego stanu rzeczy. Często są to obszary o najwyższych walorach przyrodniczych (np. parki narodowe, rezerwaty, atrakcyjne turystycznie obszary o niskiej chłonności ekologicznej) $\mathrm{i}$ ich wyłączenie z powszechnego korzystania ma na celu ograniczenie presji na nie ze strony turystyki. Z oczywistych względów znaczne ograniczenia występują na wodach granicznych i obszarach morskich oraz na

zarządzenie porządkowe Nr 11 Dyrektora Urzędu Morskiego w Gdyni z dnia 9 czerwca 2006 r. w sprawie zapewnienia bezpieczeństwa osób pływających, kąpiących się oraz uprawiających sporty wodne, Dz. Urz. Woj. Pomorskiego z 2006 r. Nr 66, poz. 1398; zarządzenie porządkowe Nr 15 Dyrektora Urzędu Morskiego w Gdyni z dnia 27 lipca 2006 r. w sprawie zapewnienia bezpieczeństwa osób pływających, kąpiących się, uprawiających sporty wodne, Dz. Urz. Woj. Pomorskiego z 2006 r. Nr 90, poz. 1874; zarządzenie porządkowe Nr 12 Dyrektora Urzędu Morskiego w Gdyni z dnia 5 lipca 2007 r. w sprawie bezpieczeństwa osób pływających, kąpiących się oraz uprawiających sporty wodne, Dz. Urz. Woj. Pomorskiego z 2007 r. Nr 124, poz. 2228; zarządzenie porządkowe Nr 3 Dyrektora Urzędu Morskiego w Szczecinie z dnia 30 lipca 2007 r. w sprawie warunków uprawiania żeglugi na wodach morskich w celach rekreacyjno-sportowych, Dz. Urz. Woj. Zachodniopomorskiego z 2007 r. Nr 88, poz. 1476; zarządzenie porządkowe Nr 1 Dyrektora Urzędu Morskiego w Słupsku z dnia 29 lipca 2010 r. w sprawie warunków uprawiania żeglugi na wodach morskich w celach rekreacyjno-sportowych, Dz. Urz. Woj. Pomorskiego z 2010 r. Nr 143, poz. 2803, Dz. Urz. Woj. Zachodniopomorskiego z 2010 r. Nr 115, poz. 2113; zarządzenie porządkowe Nr 14 Dyrektora Urzędu Morskiego w Gdyni z dnia 17 lipca 2013 r. w sprawie warunków uprawiania żeglugi na wodach morskich w celach rekreacyjno-sportowych, Dz. Urz. Woj. Pomorskiego z 2013 r. poz. 2868, Dz. Urz. Woj. Warmińsko-Mazurskiego z 2013 r. poz. 2425; zarządzenie porządkowe Nr 5 Dyrektora Urzędu Morskiego w Gdyni z dnia 3 kwietnia 2014 r. w sprawie ustanowienia warunków bezpiecznego uprawiania żeglugi na obszarze morskim wewnętrznej Zatoki Puckiej, Dz. Urz. Woj. Pomorskiego z 2014 r. poz. 1416, Dz. Urz. Woj. Warmińsko-Mazurskiego z 2014 r. poz. 1492.

10 Zob. zarządzenie Nr 3 Dyrektora Urzędu Morskiego w Szczecinie z dnia 26 lipca 2013 r. - Przepisy portowe, Dz. Urz. Woj. Zachodniopomorskiego z 2013 r. poz. 2932 z późn. zm.; zarządzenie nr 1 Dyrektora Urzędu Morskiego w Słupsku z dnia 28 kwietnia 2014 r. - Przepisy portowe, Dz. Urz. Woj. Pomorskiego z 2014 r. poz. 2157 z późn. zm. i Dz. Urz. Woj. Zachodniopomorskiego z 2014 r. poz. 2323 z późn. zm.; zarządzenie Nr 5 Dyrektora Urzędu Morskiego w Gdyni z dnia 20 lutego 2013 r. - Przepisy portowe, Dz. Urz. Woj. Pomorskiego z 2013 r. poz. 1314 z późn. zm. i Dz. Urz. Woj. Warmińsko-Mazurskiego z 2013 r. poz. 1006 z późn. zm. 
terenach wojskowych. Wreszcie niektóre obszary wodne są zamknięte dla uprawiania turystycznych wędrówek wodnych ze względów bezpieczeństwa (np. na oznakowanych kąpieliskach i akwenach szkoleniowych).

Celem niniejszego opracowania jest zbadanie i opisanie, jakie ograniczenia w zakresie uprawiania turystyki wodnej na granicznych wodach śródlądowych i obszarach morskich Rzeczypospolitej Polskiej wynikają z przepisów prawa oraz wskazanie zmian, jakich dokonano w tychże przepisach na przestrzeni ostatnich lat. Przedmiotem badań są zarówno akty normatywne powszechnie obowiązujące, jak i pragmatyki służbowe instytucji zajmujących się kontrolą ruchu granicznego. W związku z postawionym celem postępowania badawczego został sformułowany następujący problem główny: w jakim stopniu przepisy prawa ograniczają uprawianie turystyki wodnej na granicznych wodach śródlądowych i obszarach morskich Rzeczypospolitej Polskiej. W odniesieniu do problemu głównego hipoteza badawcza brzmi: przepisy prawa przewidują ograniczenia w zakresie uprawiania turystyki wodnej na granicznych wodach śródlądowych i obszarach morskich Rzeczypospolitej Polskiej, jednak ograniczenia te są konieczne i nie wpływają w istotny sposób na możliwość uprawiania tego rodzaju turystyki. Przy pisaniu artykułu zastosowano metody dogmatyczno-prawną oraz analityczną.

\section{Uprawianie turystyki wodnej na śródlądowych wodach granicznych}

Z punktu widzenia możliwości uprawiania turystyki wodnej na śródlądowych wodach granicznych kluczowe znaczenie miało wejście Polski do tzw. strefy Schengen, co nastąpiło 21 grudnia 2007 r. Zgodnie z przepisami tzw. Kodeksu granicznego Schengen ${ }^{11}$ istnieją dwa rodzaje granic państwa: granice wewnętrzne, którymi są m.in. wspólne granice lądowe państw członkowskich Unii Europejskiej, w tym granice na rzekach i jeziorach, oraz granice zewnętrzne - są nimi m.in. granice lądowe, w tym granice na rzekach i jeziorach, pod warunkiem, że nie stanowią one granic wewnętrznych (w praktyce oznacza to, że granicami zewnętrznymi są

11 Zob. art. 2 pkt 1 i 2 rozporządzenia Parlamentu Europejskiego i Rady (UE) nr 2016/399 z dnia 9 marca 2016 r. w sprawie unijnego kodeksu zasad regulujących przepływ osób przez granice (kodeks graniczny Schengen); Dz. Urz. UE L 77 z 23.03.2016, s. 1. 
granice z państwami niebędącymi członkami Unii Europejskiej). Zgodnie z art. 5 ust. 1 oraz 22 Kodeksu przekraczanie granic zewnętrznych dozwolone jest jedynie na przejściach granicznych i w ustalonych godzinach ich otwarcia, zaś granice wewnętrzne mogą być przekraczane w każdym miejscu bez dokonywania odprawy granicznej.

W związku z powyższym na nieco innych warunkach można uprawiać turystykę wodną na śródlądowych wodach granicznych z państwami strefy Schengen, a więc z Republiką Federalną Niemiec, Republiką Czeską, Republiką Słowacką oraz Republiką Litewską, na nieco innych zaś na śródlądowych wodach granicznych z państwami sąsiednimi, niebędącymi państwami tej strefy, czyli Ukrainą, Republiką Białorusi i Federacją Rosyjską (Obwodem Kaliningradzkim).

Jeśli chodzi o uprawianie turystyki wodnej na śródlądowych wodach granicznych z państwami strefy Schengen, to nie ma w tym zakresie ograniczeń przewidzianych przez prawo, co oznacza, że granicę państwa można przekraczać $\mathrm{w}$ dowolnym miejscu, nie zaś jedynie na przejściach granicznych (o ile przepisy dla danego terenu, np. parku narodowego, rezerwatu przyrody, nie stanowią inaczej) i o dowolnej porze. Należy jednak pamiętać, że na terytorium państwa sąsiedniego, np. w rejonie granicy może być prowadzona kontrola, której celem jest chociażby walka z przestępczością transgraniczną oraz kontrola bezpieczeństwa (nie jest to odprawa graniczna). Zgodnie ze stanowiskiem Sądu Najwyższego wyrażonym w wyroku z dnia 21 kwietnia 2016 r. (sygn. akt V KK 100/16) w czasie przekraczania granicy wewnętrznej państwa nie ma konieczności posiadania przy sobie dowodu osobistego lub paszportu oraz osoba nie może być zobowiązana do legitymowania się przed kimkolwiek jednym $\mathrm{z}$ tych dokumentów ${ }^{12}$. W praktyce jednak, przekraczając granicę, warto mieć przy sobie taki dokument, ponieważ Straż Graniczna nadal stoi na stanowisku, że „aby przekroczyć granice wewnętrzne trzeba posiadać ważny dokument do tego uprawniający"13.

12 http://www.sn.pl/sites/orzecznictwo/orzeczenia3/v\%20kk\%20100-16.pdf [dostęp: 15.09.2019 r.]. Co prawda poszczególne państwa strefy Schengen mogą ustanowić odrębne przepisy, zobowiązujące do posiadania przy sobie określonych dokumentów, ale Polska takich regulacji nie wprowadziła (zgodnie z brzmieniem odpowiednich ustaw dokumenty tożsamości jedynie uprawniają do przekroczenia granicy).

13 https://www.strazgraniczna.pl/pl/niezbednik-podroznego/przekraczanie-granic/2031,Przekraczanie-granic.html [dostęp: 15.09.2019 r.]. Straż Graniczna odwołuje się do wiążącej ją interpretacji przepisów prawa dokonanej przez Prokuraturę Generalną. Otóż 
Inaczej wygląda sytuacja, jeśli chodzi o uprawianie turystyki na śródlądowych wodach granicznych $\mathrm{z}$ państwami, które nie znajdują się w strefie Schengen. Szczegółowe wymogi w tym zakresie zawierają: rozporządzenie Ministra Spraw Wewnętrznych i Administracji z dnia 21 kwietnia 2008 r. $^{14}$, dwustronne umowy międzypaństwowe oraz przepisy porządkowe właściwych miejscowo wojewodów.

I tak rozporządzenie z dnia 21 kwietnia 2008 r. nakłada w § 3 obowiązek uprzedniego powiadomienia właściwego miejscowo komendanta placówki Straży Granicznej o zamiarze poruszania się jednostką pływającą po odcinku granicznym rzeki. Ponieważ chodzi o powiadomienie, które ze swej natury ma charakter informacyjny, a nie uzyskanie zgody, komendant placówki Straży Granicznej nie może ani odmówić jej udzielenia, ani żądać np. zmiany terminu. W obecnym stanie prawnym obowiązek powiadomienia należy spełnić nie później niż na dwie godziny od rozpoczęcia poruszania się po odcinku granicznym rzeki. Powiadomienia dokonuje osoba fizyczna, a w przypadku imprez zorganizowanych - jej organizator. Uprawianie turystyki z wykorzystaniem sprzętu pływającego może się odbywać do granicy państwowej tylko w porze dziennej, zaczynającej się pół godziny po wschodzie słońca, a kończącej się pół godziny przed zachodem słońca, o ile umowy międzynarodowe nie stanowią inaczej.

Z kolei w myśl postanowień umów dwustronnych, które Polska zawarła z państwami sąsiednimi, na rzekach nieżeglownych obiekty pływające mogą pływać tylko do linii granicy, natomiast na rzekach żeglownych (w tym przypadku rzeka Bug od ujścia rzeki Muchawiec do miejscowości Niemirów $)^{15}$ mają prawo pływania bez przeszkód na całej szerokości głównego nurtu, niezależnie od przechodzącej po nim linii granicy.

w 2010 r. Sąd Najwyższy wydał wyrok, w którym tak jak w wyroku z 2016 r. uznał, że do przekraczania granic wewnętrznych UE nie jest wymagane legitymowanie się dokumentem tożsamości ani jego posiadanie. Wówczas w odpowiedzi na pytanie Straży Granicznej Prokuratura Generalna stwierdziła, że „przekroczenie granicy państwowej, będącej granicą wewnętrzną UE, przez osobę nieposiadającą dokumentu uprawniającego do jej przekraczania, w zależności od okoliczności, stanowić może wykroczenie z art. 49a K.w. lub występek z art. 264 § 2 K.k.", zob. http:/ / turystyka.wp.pl/kat,1036541,title,Strefa-Schengen-za-granice-bez-dowodu,wid,18306480,wiadomosc.html?ticaid=1178c0 [dostęp: 15.09.2019 r.].

14 Zob. rozporządzenie Ministra Spraw Wewnętrznych i Administracji z dnia 21 kwietnia 2008 r. w sprawie warunków uprawiania turystyki, sportu, polowań i połowu ryb w strefie nadgranicznej, Dz. U. z 2008 r. Nr 80, poz. 481.

15 Zob. pkt 3 załącznika do rozporządzenia Rady Ministrów z dnia 26 czerwca 2019 r. w sprawie śródlądowych dróg wodnych, Dz. U. z 2019 r. poz. 1208. 
Przybicie do brzegu obcego państwa może być uzasadnione tylko w stanie wyższej konieczności (burza, awaria i inne) lub ze względu na akcję niesienia pomocy w sytuacjach zagrożenia życia (pożar) ${ }^{16}$.

W pasie drogi granicznej i strefie nadgranicznej ${ }^{17}$ należy przestrzegać przepisów porządkowych ujętych w rozporządzeniu porządkowym. Dla uprawiających turystykę wodną istotne znaczenie mogą mieć następujące zakazy: fotografowania i filmowania obiektów, znaków i urządzeń granicznych oraz terenów poza linią granicy państwowej, bezpośredniego komunikowania się przez granicę państwową oraz przerzucania lub przejmowania przez linię graniczną jakichkolwiek przedmiotów, kąpieli w rzece granicznej, z wyjątkiem miejsc do tego wyznaczonych i oznakowanych. Zabronione jest również wchodzenie na pas drogi granicznej na odcinkach, gdzie obowiązuje zakaz. Ponadto na obszarze województwa warmińsko-mazurskiego obowiązuje zakaz przebywania w porze nocnej, zaczynającej się pół godziny przed zachodem słońca, a kończącej się pół godziny po wschodzie słońca, na akwenach w odległości mniejszej niż 150 metrów od granicy państwowej, a także kąpieli w wodach granicznych w odległości mniejszej niż 15 metrów, licząc w głąb kraju od linii granicy państwowej, z wyjątkiem miejsc do tego wyznaczonych ${ }^{18}$.

16 Zob. art. 3, 4 i 13 obowiązującej na zasadzie sukcesji umowy między Rządem Polskiej Rzeczypospolitej Ludowej a Rządem Związku Socjalistycznych Republik Radzieckich o stosunkach prawnych na polsko-radzieckiej granicy państwowej oraz współpracy i wzajemnej pomocy w sprawach granicznych, podpisanej w Moskwie dnia 15 lutego 1961 r., Dz. U. z 1961 r. Nr 47, poz. 253 oraz art. 18 umowy między Rzecząpospolitą Polską a Ukrainą o stosunkach prawnych na polsko-ukraińskiej granicy państwowej oraz współpracy i wzajemnej pomocy w sprawach granicznych, sporządzonej w Kijowie dnia 12 stycznia 1993 r., Dz. U. z 1994 r. Nr 63, poz. 267.

17 Zgodnie $\mathrm{z}$ art. 9 ust. 1 ustawy o ochronie granicy pasem drogi granicznej jest obszar o szerokości 15 metrów, licząc w głąb kraju od linii granicy państwowej lub od brzegu wód granicznych albo brzegu morskiego. Natomiast zgodnie z art. 12 ust. 1 ustawy o ochronie granicy strefa nadgraniczna obejmuje cały obszar gmin przyległych do granicy państwowej, a na odcinku morskim - do brzegu morskiego. Jeżeli określona w ten sposób szerokość strefy nadgranicznej nie osiąga $15 \mathrm{~km}$, włącza się do strefy nadgranicznej również obszar gmin bezpośrednio sąsiadujących z gminami przyległymi do granicy państwowej lub brzegu morskiego.

18 Zob. rozporządzenie nr 24/07 Wojewody Podlaskiego z dnia 20 grudnia 2007 r. w sprawie wprowadzenia zakazu przebywania na niektórych odcinkach pasa drogi granicznej, Dz. Urz. Woj. Podlaskiego z 2007 r. Nr 287, poz. 3362 z późn. zm.; § 1 rozporządzenia porządkowego nr 101 Wojewody Warmińsko-Mazurskiego z dnia 22 września 2009 r. $\mathrm{w}$ sprawie przepisów porządkowych obowiązujących $\mathrm{w}$ pasie drogi granicznej i strefie 
W tym miejscu warto zwrócić uwagę na nowe możliwości uprawiania turystyki wodnej z wykorzystaniem kajaka, houseboata (barki) czy jachtu motorowego, jakie daje otwarcie w 2006 r. na Kanale Augustowskim polsko-białoruskiego rzecznego przejścia granicznego Rudawka-Lesna$\mathrm{ja}^{19}$. Zgodnie z dekretem nr 318 Prezydenta Białorusi „O wprowadzeniu bezwizowego trybu wjazdu i wyjazdu cudzoziemców" ${ }^{20}$ od 26 października 2016 r. obcokrajowcy chcący odwiedzić białoruską część Kanału Augustowskiego i okolice mogli przebywać na Białorusi do pięciu dni bez wiz. Dekret obowiązywał do 31 grudnia 2017 r. W dniu 26 grudnia 2017 r. Prezydent Białorusi wydał dekret nr 462 „O ustanowieniu bezwizowego wjazdu i wyjazdu obcokrajowców" z mocą obowiązywania od 1 stycznia 2018 r., umożliwiający przebywanie na terytorium Białorusi do dziesięciu dni. Ponadto została powiększona strefa bezwizowa - objęła ona rejon grodzieński, który w całości został włączony do Parku Rekreacyjno-Turystycznego „Kanał Augustowski”. Od 10 listopada 2019 r. dwie strefy

nadgranicznej na terenie Województwa Warmińsko-Mazurskiego, Dz. Urz. Woj. Warmińsko-Mazurskiego z 2009 r. Nr 142, poz. 2070 z późn. zm.; § 2 rozporządzenia nr 15/09 Wojewody Podkarpackiego z dnia 19 października 2009 r. w sprawie ustanowienia przepisów porządkowych obowiązujących w strefie nadgranicznej, Dz. Urz. Woj. Podkarpackiego z 2009 r. Nr 78, poz. 1802 z późn. zm.; rozporządzenie nr 16/09 Wojewody Podkarpackiego z dnia 19 października 2009 r. w sprawie wprowadzenia zakazu przebywania na niektórych odcinkach pasa drogi granicznej, Dz. Urz. Woj. Podkarpackiego z 2009 r. Nr 78, poz. 1803 z późn. zm.; § 1 rozporządzenia porządkowego nr 5 Wojewody Lubelskiego z dnia 30 lipca 2010 r. w sprawie przepisów porządkowych obowiązujących w pasie drogi granicznej i w strefie nadgranicznej na terenie województwa lubelskiego, Dz. Urz. Woj. Lubelskiego z 2010 r. Nr 89, poz. 1631; rozporządzenie nr 1 Wojewody Warmińsko-Mazurskiego z dnia 19 stycznia 2012 r. w sprawie wprowadzenia zakazu przebywania na odcinkach pasa drogi granicznej, Dz. Urz. Woj. Warmińsko-Mazurskiego z 2012 r. poz. 257; rozporządzenie nr 1 Wojewody Lubelskiego z dnia 2 lutego 2015 r. w sprawie wprowadzenia zakazu przebywania na niektórych odcinkach pasa drogi granicznej, Dz. Urz. Woj. Lubelskiego z 2015 r. poz. 466.

19 Zob. porozumienie z dnia 4 listopada 2005 r. między Rządem Rzeczypospolitej Polskiej a Rządem Republiki Białorusi o otwarciu przejścia granicznego Rudawka-Lesnaja na Kanale Augustowskim, M.P. z 2006 r. Nr 26, poz. 292 oraz oświadczenie rządowe z dnia 23 stycznia 2006 r. w sprawie związania Rzeczypospolitej Polskiej Porozumieniem z dnia 4 listopada 2005 r. między Rządem Rzeczypospolitej Polskiej a Rządem Republiki Białorusi o otwarciu przejścia granicznego Rudawka-Lesnaja na Kanale Augustowskim, M.P. z 2006 r. Nr 26, poz. 293.

20 Ukaz Priezidienta Riespubliki Biełarus' ot 23 awgusta 2016 g. No 318 Ob ustanowlenii biezwizowogo poriadka wjezda i wyjezda inostrannych grażdan, http:/ / www.pravo.by/document/?guid=12551\&p0=P31600318\&p1=1 [dostęp: 15.09.2019 r.]. 
bezwizowe - wokół Grodna i Brześcia - połączono w jedną i powiększono jej obszar. Na obszarze strefy obywatele 77 państw (w tym Polski oraz innych państw Unii Europejskiej) mogą przebywać do 15 dób ${ }^{21}$.

Aby przekroczyć granicę, cudzoziemiec musi posiadać ważny paszport lub inny dokument uprawniający do przekroczenia granicy, dokument uprawniający do indywidualnego lub grupowego zwiedzania Parku Rekreacyjno-Turystycznego "Kanał Augustowski” (potwierdzający wykupienie usług turystycznych), wydany przez białoruskie biuro podróży, świadczące usługi turystyczne na terenie parku ${ }^{22}$ (lista biur podróży została zamieszczona na stronie internetowej ambasady Białorusi) ${ }^{23}$, ubezpieczenie medyczne oraz środki finansowe - ruble białoruskie, dolary amerykańskie, euro lub inne dewizy w kwocie o równowartości co najmniej 24 dolarów amerykańskich na każdy dzień pobytu. Wprowadzenie na Kanale Augustowskim ruchu bezwizowego spowodowało znaczne zwiększenie liczby turystów przekraczających granicę jednostką pływającą ${ }^{24}$.

Z podobną inicjatywą, a mianowicie otworzenia w okresie letnim wodnego przejścia granicznego z Federacją Rosyjską (Obwód Kaliningradzki) na rzece Łynie przed kilku laty wystąpiło Starostwo Powiatowe w Bartoszycach, Stowarzyszenie „Ożywić Łynę” i Stowarzyszenie Samorządów Przygranicznych Euroregionu Łyna-Ława. Dotychczasowe starania nie przyniosły jednak oczekiwanego rezultatu ${ }^{25}$. Od 2000 r. corocznie w czerwcu odbywa się Międzynarodowy Spływ Kajakowy „Łyna-Ława” od miejscowości Stopki (RP) do miejscowości Temkino (rejon Prawdińsk) ${ }^{26}$.

21 Zob. Ukaz Priezidienta Riespubliki Biełarus' ot 7 awgusta 2019 g. No 300 Ob ustanowlenii biezwizowogo poriadka wjezda i wyjezda inostrannych grażdan, http://president.gov.by/uploads/documents/2019/300uk.pdf [dostęp 25.03.2020 r.].

22 Wzór dokumentu uprawniającego do wejścia na teren białoruskiego parku Kanał Augustowski został wskazany w rozporządzeniu białoruskiego rządu z dnia 17 października 2016 r., http:/ / www.government.by/ru/solutions/2658 [dostęp: 15.09.2019 r.]; zob. też http://www.rp.pl/Promocja-turystyczna/310259898-Caly-Kanal-Augustowski -dostepny-bez-wizy.html\#ap-1 [dostęp: 15.09.2019 r.].

23 https://grodnovisafree.by/pl/operatorzy-turystyczni.html [dostęp: 15.09.2019 r.].

24 http://www.rp.pl/Obyczaje/308069971-Siedem-razy-wiecej-turystow-na-granicy-z-Bialorusia.html\#ap-1 [dostęp: 15.09.2019 r.].

25 http:/ / fakty.interia.pl/warminsko-mazurskie/news-bedzie-przejscie-graniczne-na-lynie,nId,1203970 [dostęp: 15.09.2019 r.].

26 http://sepopol.wm.pl/364670,Odprawa-graniczna-kajakarzy-na-Lynie. html\#axzz4H2L6UZjF [dostęp: 15.09.2019 r.]; https://sepopol.pl/PL/drukuj/1000/202/ XIX_Miedzynarodowy_splyw_Lyna_-_Lawa_2019/wersja/ [dostęp: 15.09.2019 r.]. 


\section{Uprawianie turystyki wodnej na granicznych obszarach morskich}

Jeżeli chodzi o uprawianie turystyki wodnej na wodach morskich w pobliżu granicy państwowej, to istnieją ograniczenia, które dotyczą Zalewu Wiślanego. Osoby uprawiające turystykę wodną na tym akwenie są zobowiązane do przestrzegania zakazu przebywania w porze nocnej, zaczynającej się pół godziny przed zachodem słońca, a kończącej się pół godziny po wschodzie słońca, nad brzegiem Zalewu w odległości mniejszej niż $250 \mathrm{~m}$ od granicy państwowej ${ }^{27}$. Zgodnie z art. 2 dwustronnej umowy polsko-rosyjskiej podpisanej w $2009 \mathrm{r}^{28}$ turystyka wodna może być uprawiana na polskich jednostkach rekreacyjnych również na części Zalewu na terytorium Federacji Rosyjskiej, ale po wcześniejszym przekroczeniu polsko-rosyjskiej granicy państwowej na Zalewie i pod warunkiem wykonywania żeglugi w sposób zgodny z przepisami prawa rosyjskiego. Odprawa graniczna jest prowadzona w morskich przejściach granicznych Elbląg lub Frombork. Zgłoszenie do odprawy powinno się odbywać za pośrednictwem Kapitanatu Portu w Elblągu lub Bosmanatu Portu we Fromborku. Ponadto można również zgłosić jednostkę do odprawy bezpośrednio w Placówce Straży Granicznej w Elblągu ${ }^{29}$. Uczestnik rejsu powinien posiadać ważny dokument stwierdzający tożsamość, czyli paszport, oraz wizę, o czym stanowi art. 1 umowy między Rządem Rzeczypospolitej Polskiej a Rządem Federacji Rosyjskiej o warunkach podróży obywateli Rzeczypospolitej Polskiej i obywateli Federacji Rosyjskiej, podpisanej w Warszawie dnia 18 września $2003 \mathrm{r} .{ }^{30} \mathrm{~W}$ przypadku pobytu na jednostce rekreacyjnej osoby, która nie jest obywatelem Polski lub Rosji, procedury odprawy nie ulegają zmianie, z tym że osoba taka nie musi posiadać wizy, jeśli jest obywatelem państwa, które podpisało umowę

27 Zob. § 1 ust. 1 pkt 3 rozporządzenia porządkowego nr 101 Wojewody Warmińsko-Mazurskiego z dnia 22 września 2009 r. w sprawie przepisów porządkowych obowiązujących w pasie drogi granicznej i strefie nadgranicznej na terenie Województwa Warmińsko-Mazurskiego, Dz. Urz. Woj. Warmińsko-Mazurskiego z 2009 r. Nr 142, poz. 2070 z późn. zm.

28 Zob. umowę między Rządem Rzeczypospolitej Polskiej i Rządem Federacji Rosyjskiej o żegludze po Zalewie Wiślanym (Kaliningradskij zaliw), podpisaną w Sopocie dnia 1 września 2009 r., M.P. z 2009 r. Nr 78, poz. 975.

29 Zob. § 8 zarządzenia nr 12 Dyrektora Urzędu Morskiego w Gdyni z dnia 12 listopada 2003 r. w sprawie zasad uprawiania żeglugi na Zalewie Wiślanym.

30 M.P. z 2003 r. Nr 51, poz. 800. 
z Federacją Rosyjską o zniesieniu obowiązku wizowego. Jeżeli zaś dany obywatel państwa trzeciego jest objęty obowiązkiem wizowym w Rzeczypospolitej Polskiej i posiada wizę z prawem do jednokrotnego wjazdu, to $\mathrm{w}$ momencie jego wyjazdu do Federacji Rosyjskiej ulegnie ona wykorzystaniu i tym samym nie może on wjechać ponownie na podstawie tej samej wizy do Polski.

\section{Konsekwencje prawne nieprzestrzegania przepisów prawnych ograniczających uprawianie turystyki wodnej na granicznych wodach śródlądowych i obszarach morskich oraz kompetencje organów czuwających nad przestrzeganiem tychże przepisów}

Przekroczenie lądowej granicy państwowej Rzeczypospolitej w miejscu niedozwolonym (poza przejściem granicznym $\mathrm{w}$ ustalonych godzinach jego otwarcia) jest wykroczeniem, którego sprawca może być ukarany przez sąd grzywną w wysokości od 20 do 5000 zł, przy czym karalne jest również usiłowanie przekroczenia granicy ${ }^{31}$. W doktrynie istnieje spór odnośnie do tego, czy wykroczenie to można popełnić przez działanie lub zaniechanie wyłącznie o charakterze umyślnym, czy również nieumyślnym. Według jednego stanowiska stosownie do zasady wyrażonej w art. 5 K.w. wykroczenie to można popełnić zarówno umyślnie, jak i nieumyślnie, bowiem $\mathrm{w}$ tym przypadku ustawa nie przewiduje odpowiedzialności tylko za wykroczenie umyślne ${ }^{32}$. Z kolei reprezentanci odmiennego stanowiska uważają, że wykroczenie, o którym mowa w art. 49a K.w. może być popełnione umyślnie, wyłącznie w zamiarze bezpośrednim, co wynika z użytego przez ustawodawcę wyrazu "przekracza”, wskazującego na zachowanie sprawcy ${ }^{33}$. Jak wykazano w literaturze przedmiotu, za

31 Zob. art. 49a w zw. z art. 24 § 1 ustawy z dnia 20 maja 1971 r. - Kodeks wykroczeń, tekst jednolity: Dz. U. z 2019 r. poz. 821 (dalej: K.w.).

32 Zob. W. Jankowski, Komentarz do art. 49(a) Kodeksu wykroczeń, w: Kodeks wykroczeń. Komentarz, red. T.H. Grzegorczyk, 2013 [wyd. el. LEX]; M. Mozgawa, Komentarz do art. 49(a) Kodeksu wykroczeń, w: Kodeks wykroczeń. Komentarz, red. M. Mozgawa, 2009 [wyd. el. LEX].

33 Zob. W. Kotowski, Komentarz do art. 49(a) Kodeksu wykroczeń, w: Kodeks wykroczeń. Komentarz, Warszawa-Kraków 2009; M. Jachimowicz, Nowe zasady odpowiedzialności za nielegalne przekroczenie granicy RP, Prokuratura i Prawo 2006, nr 5, s. 51. 
słuszne należy uznać stanowisko, zgodnie z którym strona podmiotowa analizowanego wykroczenia może polegać zarówno na umyślności, jak i nieumyślności ${ }^{34}$.

Na podstawie rozporządzenia Ministra Spraw Wewnętrznych z dnia 18 kwietnia $2014 \mathrm{r}^{35}$ uprawnienia do nakładania grzywien $\mathrm{w}$ drodze mandatu karnego w wysokości od 20 do 500 zł za popełnione wykroczenie uzyskali funkcjonariusze Straży Granicznej. Niezastosowanie się do zakazów zawartych w przepisach porządkowych regulujących uprawianie turystyki wodnej na wodach granicznych ${ }^{36}$ również może skutkować pociągnięciem przez funkcjonariusza Straży Granicznej do odpowiedzialności za popełnione wykroczenie. Większość przepisów porządkowych przewiduje karę grzywny w wysokości do $500 \mathrm{z}^{37}$. Jeżeli zaś przepisy porządkowe stanowią normę niezabezpieczoną, wówczas zastosowanie znajdzie art. 54 K.w., przewidujący karę grzywny do $500 \mathrm{zł}$ albo karę nagany. Ponadto w przypadku kąpieli w miejscu, w którym jest to zabronione, może mieć zastosowanie art. $55 \mathrm{~K} . w .$, zgodnie z którym osoba kąpiąca się podlega karze grzywny do 250 zł albo karze nagany. Funkcjonariusz Straży Granicznej w momencie stwierdzenia popełnienia wykroczenia może zrezygnować

34 K. Banasik, Penalizacja bezprawnego przekroczenia granicy państwowej, Studia Prawnicze. Rozprawy i Materiały 2017, nr 1, s. 9-10.

35 Zob. § 2 pkt 1 rozporządzenia Ministra Spraw Wewnętrznych z dnia 18 kwietnia 2014 r. w sprawie wykroczeń, za które funkcjonariusze Straży Granicznej są uprawnieni do nakładania grzywien w drodze mandatu karnego, Dz. U. z 2014 r. poz. 539 z późn. zm.; zob. też art. 11 ust. 1 pkt 6a ustawy z dnia 12 października 1990 r. o Straży Granicznej, tekst jednolity: Dz. U. z 2020 r. poz. 305.

36 Uprawnienie do nakładania grzywien w drodze mandatu karnego za wykroczenia określone w rozporządzeniach porządkowych obowiązujących w strefie nadgranicznej, wydanych przez wojewodę funkcjonariusze Straży Granicznej nabyli na podstawie § 2 pkt 13 rozporządzenia Ministra Spraw Wewnętrznych z dnia 18 kwietnia 2014 r. w sprawie wykroczeń, za które funkcjonariusze Straży Granicznej są uprawnieni do nakładania grzywien w drodze mandatu karnego.

37 Zob. § 4 rozporządzenia porządkowego nr 5 Wojewody Lubelskiego z dnia 30 lipca 2010 r. w sprawie przepisów porządkowych obowiązujących w pasie drogi granicznej i w strefie nadgranicznej na terenie województwa lubelskiego; 3 rozporządzenia porządkowego nr 101 Wojewody Warmińsko-Mazurskiego z dnia 22 września 2009 r. w sprawie przepisów porządkowych obowiązujących w pasie drogi granicznej i strefie nadgranicznej na terenie Województwa Warmińsko-Mazurskiego; § 7 rozporządzenia nr 15/09 Wojewody Podkarpackiego z dnia 19 października 2009 r. w sprawie ustanowienia przepisów porządkowych obowiązujących w strefie nadgranicznej, Dz. Urz. Woj. Podkarpackiego z 2009 r. Nr 78, poz. 1802 z późn. zm. 
z wymierzenia kary i poprzestać na posłużeniu się środkiem wskazanym w art. 41 K.w., czyli zastosować pouczenie, zwrócić uwagę, ostrzec lub zastosować inny środek oddziaływania wychowawczego.

Stosownie do art. 11 ustawy z dnia 12 października 1990 r. o Straży Granicznej funkcjonariusze mają prawo m.in. do legitymowania lub ustalania w inny sposób tożsamości osoby, przeszukania osoby, rzeczy, środków transportu, a także zatrzymania osoby, gdyby inne środki okazały się bezcelowe lub nieskuteczne.

W przypadku gdy uprawiający turystykę wodną bezprawnie przekroczy granicę państwową i zostanie zatrzymany przez odpowiednie organy ochrony granicy państwa sąsiedniego, zgodnie z postanowieniami umów dwustronnych powinien „w możliwie krótkim czasie” zostać przekazany pełnomocnikowi granicznemu po stronie polskiej, pod warunkiem, że do przekroczenia doszło nieumyślnie ${ }^{38}$. Natomiast jeśli granica zostanie przekroczona nielegalnie umyślnie, wówczas odpowiednie organy ochrony granicy obcego państwa, uznawszy za potrzebne uzyskanie dodatkowych wyjaśnień, mogą zatrzymać osobę na czas niezbędny w celu ich uzyskania, zawiadamiając pełnomocnika granicznego drugiej strony, i dopiero po złożeniu wyjaśnień przekazać właściwym służbom strony polskiej (w przypadku nielegalnego przekroczenia granicy polsko-ukraińskiej przekazanie osoby powinno nastąpić z reguły do 12 godzin od chwili otrzymania wniosku od strony polskiej). Decyzję w sprawie przekazania zatrzymanej osoby podejmują „właściwe naczelne władze strony zatrzymującej", przy czym może mieć miejsce sytuacja, że osoba nie zostanie przekazana stronie polskiej, jeżeli oprócz przestępstwa nielegalnego przekroczenia granicy dokonała innego czynu stanowiącego przestępstwo według prawa państwa, na którego terytorium przeszła. Ponadto przekazanie może nie nastąpić „z jakichkolwiek innych przyczyn” ${ }^{39}$. Niestety

38 Zob. art. 40 umowy między Rządem Polskiej Rzeczypospolitej Ludowej a Rządem Związku Socjalistycznych Republik Radzieckich o stosunkach prawnych na polsko-radzieckiej granicy państwowej oraz współpracy i wzajemnej pomocy w sprawach granicznych, podpisanej w Moskwie dnia 15 lutego 1961 r. oraz art. 48 umowy między Rzecząpospolitą Polską a Ukrainą o stosunkach prawnych na polsko-ukraińskiej granicy państwowej oraz współpracy i wzajemnej pomocy w sprawach granicznych.

${ }_{39}$ Zob. art. 41 umowy między Rządem Polskiej Rzeczypospolitej Ludowej a Rządem Związku Socjalistycznych Republik Radzieckich o stosunkach prawnych na polsko-radzieckiej granicy państwowej oraz współpracy i wzajemnej pomocy w sprawach granicznych, podpisanej w Moskwie dnia 15 lutego 1961 r. oraz art. 49 umowy między Rzecząpospolitą 
ostatnie postanowienie jest na tyle ogólne, że umożliwia zatrzymanie osoby nie tylko wtedy, gdy jest to konieczne.

Na Zalewie Wiślanym nadzór nad przestrzeganiem przepisów prawa sprawuje w granicach właściwości terytorialnej dyrektor Urzędu Morskiego w Gdyni. Swoje kompetencje wykonuje przy pomocy m.in. inspekcji morskiej oraz Służby Kontroli Ruchu Statków (Służba VTS) ${ }^{40}$. Inspekcja morska może realizować swoje uprawnienia we współdziałaniu ze Strażą Graniczną, przy użyciu jej sił i środków, a w razie konieczności także w porozumieniu z Marynarką Wojenną. W przypadku nieobecności inspektora inspekcji morskiej na pokładzie jednostki pływającej Straży Granicznej funkcjonariusze Straży Granicznej mogą samodzielnie podejmować działania w imieniu dyrektora urzędu morskiego ${ }^{41}$. Zakres współpracy urzędów morskich z Marynarką Wojenną i Strażą Graniczną został uregulowany w rozporządzeniu Ministra Transportu i Gospodarki Morskiej z dnia 20 sierpnia 1999 r. ${ }^{42}$

Przekroczenie morskiej granicy państwowej Rzeczypospolitej w miejscach niedozwolonych - tak samo jak w przypadku przekroczenia granicy lądowej - stanowi wykroczenie, którego sprawca może być ukarany grzywną w wysokości od 20 do 5000 zł. Ochronę granicy przed jej przekraczaniem wbrew przepisom prawa zapewnia Morski Oddział Straży Granicznej, który współdziała w tym zakresie z Marynarką Wojenną ${ }^{43}$. Do zatrzymania statku, rozumianego jako każde urządzenie pływające

Polską a Ukrainą o stosunkach prawnych na polsko-ukraińskiej granicy państwowej oraz współpracy i wzajemnej pomocy w sprawach granicznych.

40 Art. 39 ust. 4 i 5 oraz art. 49 ustawy o obszarach morskich Rzeczypospolitej Polskiej i administracji morskiej.

${ }^{41}$ Art. 50 ust. 4-7 ustawy o obszarach morskich Rzeczypospolitej Polskiej i administracji morskiej.

42 Zob. rozporządzenie Ministra Transportu i Gospodarki Morskiej z dnia 20 sierpnia 1999 r. w sprawie współpracy urzędów morskich z Marynarką Wojenną i Strażą Graniczną, Dz. U. z 1999 r. Nr 75, poz. 850.

43 Zob. art. 19 ust. 2c i 2d ustawy o Straży Granicznej. Zakres współpracy Straży Granicznej z Marynarką Wojenną został uregulowany w rozporządzeniu Ministra Spraw Wewnętrznych i Administracji z dnia 29 grudnia 2004 r. w sprawie szczegółowych zasad współdziałania Straży Granicznej z Siłami Powietrznymi i Marynarką Wojenną Sił Zbrojnych Rzeczypospolitej Polskiej w zakresie ochrony granicy państwowej, tekst jednolity: Dz. U. z 2020 r. poz. 1212. Szerzej na temat ochrony polskiej granicy morskiej zob. D. Jurczak, Wybrane zagadnienia zapewnienia bezpieczeństwa na morskim odcinku ochrony granicy państwowej, Edukacja Humanistyczna 2013, nr 2, s. 200-204. 
używane w środowisku morskim, oraz do kontroli uprawniony jest dowódca jednostki pływającej. Ponadto może on wezwać statek do zmniejszenia prędkości przepływu oraz zastosowania się do wskazanego kursu przepływu. Podczas kontroli ma prawo sprawdzić dokumenty dotyczące statku, wylegitymować załogę statku oraz znajdujących się na nim pasażerów, zatrzymać osobę podejrzaną o popełnienie przestępstwa, a także zmusić statek do zawinięcia do wskazanego portu, jeżeli kapitan nie stosuje się do wydanych poleceń. Powyższe działania może on podjąć także wtedy, gdy statek wpływa na obszar strefy zamkniętej lub niebezpiecznej dla żeglugi albo narusza przepisy dotyczące bezpieczeństwa żeglugi. Jeżeli istnieje uzasadnione podejrzenie, że statek $\mathrm{w}$ czasie pobytu na morskich wodach wewnętrznych lub na morzu terytorialnym naruszył przepisy obowiązujące na terytorium Rzeczypospolitej Polskiej i mimo wezwania do zatrzymania się lub po zatrzymaniu go usiłuje zbiec, dowódca jednostki pływającej Straży Granicznej może, w celu zatrzymania statku, zarządzić wszczęcie za nim pościgu, podczas którego w sytuacjach wyjątkowych i jako środek ostateczny, gdy inne środki nie są wystarczające do zatrzymania statku lub wymuszenia posłuszeństwa, może być nawet użyta broń pokładowa ${ }^{44}$.

Istotną rolę $\mathrm{w}$ zakresie przestrzegania przepisów prawa odgrywa również Policja, a zwłaszcza Policja wodna. Do jej zadań należy m.in. zapobieganie popełnianiu przestępstw i wykroczeń na wodach śródlądowych, morzu terytorialnym oraz morskich wodach wewnętrznych, wykrywanie przestępstw i wykroczeń oraz ściganie i zatrzymywanie sprawców, w tym w szczególności naruszających przepisy w zakresie bezpieczeństwa w żegludze ${ }^{45}$. Podczas patrolowania funkcjonariusze Policji powinni w szczególności: prowadzić obserwację wód i terenów przywodnych oraz zachodzących w nich zjawisk, natychmiast reagować w każdym przypad$\mathrm{ku}$, uzasadniającym potrzebę przeprowadzenia interwencji, systematycznie kontrolować wszystkie miejsca zagrożone znajdujące się w rejonie pełnienia służby, zbierać informacje dotyczące występujących zagrożeń lub mogące się przyczynić do ustalenia sprawców przestępstw i wykroczeń,

44 Zob. art. 14 ust. 1 i ust. 2 pkt 6 i 8 oraz art. 16-18 ustawy o Straży Granicznej.

45 Zob. § 6 zarządzenia Nr 1386 Komendanta Głównego Policji z dnia 17 listopada 2009 r. w sprawie metod i form wykonywania zadań przez policjantów pełniących służbę na wodach i terenach przywodnych, tekst jednolity: Dz. Urz. Komendy Głównej Policji z 2013 r. poz. 71 z późn. zm. 
ujawniać osoby naruszające porządek publiczny oraz przeprowadzać kontrole jednostek pływających (chodzi m.in. o sprawdzenie sprawności technicznej jednostki pływającej, wymaganego prawem wyposażenia w środki bezpieczeństwa, uprawnienia do kierowania, jeżeli w przypadku danej jednostki pływającej takowe jest wymagane, dokumentu rejestracyjnego statku oraz sprawdzenie stanu trzeźwości uprawiającego turystykę wodną) $)^{46}$.

W przypadku gdy sprawca wykroczenia zostanie ujęty na gorącym uczynku lub bezpośrednio po popełnieniu wykroczenia albo też funkcjonariusz Policji stwierdzi popełnienie wykroczenia naocznie pod nieobecność sprawcy, a nie zachodzi wątpliwość, kto jest sprawcą czynu, albo stwierdzi popełnienie wykroczenia za pomocą przyrządu kontrolno-pomiarowego lub urządzenia rejestrującego, a sprawca nie został schwytany na gorącym uczynku lub bezpośrednio potem, i nie zachodzi wątpliwość co do sprawcy - może nałożyć grzywnę w drodze mandatu karnego. W pierwszym przypadku taki mandat może być nałożony w ciągu $14 \mathrm{dni}$ od daty ujawnienia czynu, w drugim - 90 dni, zaś w trzecim - 180 dni ${ }^{47}$. W sytuacji odmowy przyjęcia mandatu lub nieuiszczenia w wyznaczonym terminie grzywny nałożonej mandatem zaocznym Policja występuje do sądu z wnioskiem o ukaranie. Co do zasady funkcjonariusz Policji może nałożyć grzywnę w drodze mandatu karnego w wysokości od 20 do 500 zł, przy czym w razie popełnienia więcej niż jednego wykroczenia, możliwe jest nałożenie tylu mandatów, ile zostało stwierdzonych czynów. W przypadku tzw. zbiegu przepisów ustawy grzywna w trybie mandatowym może sięgnąć 1000 zł. Nie ma też przeszkód, aby po wyjaśnieniach sprawcy funkcjonariusz odstąpił od wymierzenia kary i ograniczył się do środka wychowawczego (art. 41 K.w.).

Według danych Policji w okresie wakacyjnym w 2014 r. w czterech komisariatach specjalistycznych (w Warszawie, Krakowie, Poznaniu i Wrocławiu) oraz sześciu komórkach wodnych działających na terenie województw: kujawsko-pomorskiego (w Bydgoszczy, Toruniu i Włocławku), pomorskiego (w Gdańsku), warmińsko-mazurskiego (w Olsztynie) oraz

46 § 20 zarządzenia Nr 1386 Komendanta Głównego Policji z dnia 17 listopada 2009 r. w sprawie metod i form wykonywania zadań przez policjantów pełniących służbę na wodach i terenach przywodnych.

47 Zob. art. 97 § 1 ustawy z dnia 24 sierpnia 2001 r. - Kodeks postępowania w sprawach o wykroczenia, tekst jednolity: Dz. U. z 2020 r. poz. 729. 
zachodniopomorskiego (w Szczecinie), a także w licznych komórkach sezonowych łącznie pełniło służbę 519 funkcjonariuszy. Ponadto znaczna część mniejszych akwenów była objęta nadzorem funkcjonariuszy pełniących służbę patrolową i obchodową ${ }^{48}$. W 2018 r. kontrolę w zakresie działań Policji wodnej na rzecz bezpieczeństwa na wodach morskich i terenach nadmorskich przeprowadziła Najwyższa Izba Kontroli. Kontrola wykazała zbyt małe zasoby kadrowe, braki w wyposażeniu oraz zbyt małe środki finansowe przeznaczane na działania Policji wodnej, co stwarza „ryzyko niezapewnienia właściwego poziomu bezpieczeństwa obywateli". NIK zwróciła również uwagę na nie w pełni właściwą strukturę organizacyjną Policji wodnej ${ }^{49}$.

\section{Zakończenie}

W Polsce na przestrzeni ostatnich lat coraz popularniejsza staje się turystyka wodna, w tym również uprawiana na granicznych wodach śródlądowych oraz obszarach morskich. Na podstawie przeprowadzonego postępowania badawczego należy stwierdzić, że obecnie obowiązujące przepisy prawa przewidują wprawdzie zakazy i ograniczenia, ale są one konieczne i nie wpływają w istotny sposób na uprawianie tego rodzaju turystyki. Oznacza to, że jej miłośnicy mają olbrzymie możliwości korzystania z zasobów wodnych. W ten sposób została potwierdzona sformułowana we wstępie hipoteza badawcza.

Bez wątpienia kluczowe znaczenie dla rozwoju turystyki nadgranicznej miało wejście Polski do tzw. strefy Schengen, gdyż dzięki temu zostały zniesione liczne zakazy i ograniczenia w dostępności do wód granicznych na granicy zachodniej i południowej. Obecnie ograniczenia i zakazy odnoszą się do granicy wschodniej i północno-wschodniej, ale jest to zrozumiałe, gdyż granica ta jest jednocześnie granicą zewnętrzną Unii Europejskiej.

Wypada zwrócić uwagę, że polskie ustawodawstwo regulujące uprawianie turystyki wodnej na granicznych wodach śródlądowych i obszarach

48 Bezpieczeństwo na wodzie. Wywiad z insp. Markiem Walczakiem Dyrektorem Biura Prewencji i Ruchu Drogowego Komendy Głównej Policji, Kwartalnik Policyjny 2014, nr 3, s. 2-3.

49 Zob. https://www.nik.gov.pl/aktualnosci/nik-o-dzialaniach-policji-wodnej-na-wodach-morskich-i-terenach-nadmorskich.html [dostęp: 15.09.2019 r.]. 
morskich jest zbyt rozbudowane i w niektórych przypadkach kazuistyczne, co należy ocenić negatywnie. Przepisy prawne znajdują się w kilkudziesięciu aktach normatywnych, ponadto często są one zmieniane. Wszystko to powoduje, że sprawiają one problemy tym, do których są adresowane, tzn. turystom - ci nie zawsze ich przestrzegają, co niejednokrotnie wynika z nieznajomości przepisów właśnie. W związku z tym należy postulować, aby ustawodawca rozważył możliwość ich uproszczenia.

W celu jeszcze szerszego udostępnienia turystom rzek granicznych oraz obszarów morskich wskazane byłoby również rozwijanie współpracy bilateralnej z państwami sąsiednimi, co powinno znaleźć odzwierciedlenie w zawieranych dwustronnych umowach międzynarodowych. Szczególnie odczuwalny jest brak takiej umowy z Republiką Białorusi (umowa zawarta w 1961 r. między Rządem PRL a Rządem ZSRR jest przestarzała i zawiera postanowienia nieadekwatne do potrzeb społeczeństw obydwu państw), która umożliwiłaby szersze wykorzystanie rzeki Bug do celów turystycznych.

\section{Bibliografia}

\section{Źródła}

\section{Akty prawne}

Oświadczenie rządowe z dnia 23 stycznia 2006 r. w sprawie związania Rzeczypospolitej Polskiej Porozumieniem z dnia 4 listopada 2005 r. między Rządem Rzeczypospolitej Polskiej a Rządem Republiki Białorusi o otwarciu przejścia granicznego Rudawka-Lesnaja na Kanale Augustowskim, M.P. z 2006 r. Nr 26, poz. 293.

Porozumienie z dnia 4 listopada 2005 r. między Rządem Rzeczypospolitej Polskiej a Rządem Republiki Białorusi o otwarciu przejścia granicznego Rudawka-Lesnaja na Kanale Augustowskim, M.P. z 2006 r. Nr 26, poz. 292.

Rozporządzenie Ministra Transportu i Gospodarki Morskiej z dnia 20 sierpnia 1999 r. w sprawie współpracy urzędów morskich z Marynarką Wojenną i Strażą Graniczną, Dz. U. z 1999 r. Nr 75, poz. 850.

Rozporządzenie Ministra Infrastruktury z dnia 28 kwietnia 2003 r. w sprawie przepisów żeglugowych na śródlądowych drogach wodnych, Dz. U. z 2003 r. Nr 212, poz. 2072. 
Rozporządzenie Ministra Spraw Wewnętrznych i Administracji z dnia 29 grudnia 2004 r. w sprawie szczegółowych zasad współdziałania Straży Granicznej z Siłami Powietrznymi i Marynarką Wojenną Sił Zbrojnych Rzeczypospolitej Polskiej w zakresie ochrony granicy państwowej, tekst jednolity: Dz. U. z 2020 r. poz. 1212.

Rozporządzenie Ministra Spraw Wewnętrznych i Administracji z dnia 21 kwietnia 2008 r. w sprawie warunków uprawiania turystyki, sportu, polowań i połowu ryb w strefie nadgranicznej, Dz. U. z 2008 r. Nr 80, poz. 481.

Rozporządzenie Ministra Spraw Wewnętrznych z dnia 18 kwietnia 2014 r. w sprawie wykroczeń, za które funkcjonariusze Straży Granicznej są uprawnieni do nakładania grzywien w drodze mandatu karnego, Dz. U. z 2014 r. poz. 539 z późn. zm.

Rozporządzenie Parlamentu Europejskiego i Rady (UE) nr 2016/399 z dnia 9 marca 2016 r. w sprawie unijnego kodeksu zasad regulujących przepływ osób przez granice (kodeks graniczny Schengen), Dz. Urz. UE L 77 z 23.03.2016.

Rozporządzenie Rady Ministrów z dnia 26 czerwca 2019 r. w sprawie śródlądowych dróg wodnych, Dz. U. z 2019 r. poz. 1208.

Ukaz Priezidienta Riespubliki Biełarus' ot 23 awgusta 2016 g. No 318 Ob ustanowlenii biezwizowogo poriadka wjezda i wyjezda inostrannych grażdan, http://www. pravo.by/document/?guid=12551\&p0=P31600318\&p1=1 [dostęp: 15.09 .2019 r.].

Ukaz Priezidienta Riespubliki Biełarus' ot 7 awgusta 2019 g. No 300 Ob ustanowlenii biezwizowogo poriadka wjezda i wyjezda inostrannych grażdan, http:// president.gov.by/uploads/documents/2019/300uk.pdf [dostęp 25.03.2020 r.].

Umowa między Rządem Polskiej Rzeczypospolitej Ludowej a Rządem Związku Socjalistycznych Republik Radzieckich o stosunkach prawnych na polsko-radzieckiej granicy państwowej oraz współpracy i wzajemnej pomocy w sprawach granicznych, podpisana w Moskwie dnia 15 lutego 1961 r., Dz. U. z 1961 r. Nr 47, poz. 253.

Umowa między Rzecząpospolitą Polską a Ukrainą o stosunkach prawnych na polsko-ukraińskiej granicy państwowej oraz współpracy i wzajemnej pomocy w sprawach granicznych, sporządzona w Kijowie dnia 12 stycznia 1993 r., Dz. U. z 1994 r. Nr 63, poz. 267.

Umowa między Rządem Rzeczypospolitej Polskiej a Rządem Federacji Rosyjskiej o warunkach podróży obywateli Rzeczypospolitej Polskiej i obywateli Federacji Rosyjskiej, podpisana w Warszawie dnia 18 września 2003 r., M.P. z 2003 r. Nr 51, poz. 800.

Umowa między Rządem Rzeczypospolitej Polskiej i Rządem Federacji Rosyjskiej o żegludze po Zalewie Wiślanym (Kaliningradskij zaliw), podpisana w Sopocie dnia 1 września 2009 r., M.P. z 2009 r. Nr 78, poz. 975.

Ustawa z dnia 20 maja 1971 r. - Kodeks wykroczeń, tekst jednolity: Dz. U. z 2019 r. poz. 821 . 
Ustawa z dnia 12 października 1990 r. o ochronie granicy państwowej, tekst jednolity: Dz. U. z 2019 r. poz. 1776.

Ustawa z dnia 12 października 1990 r. o Straży Granicznej, tekst jednolity: Dz. U. z 2020 r. poz. 305.

Ustawa z dnia 21 marca 1991 r. o obszarach morskich Rzeczypospolitej Polskiej i administracji morskiej, tekst jednolity: Dz. U. z 2019 r. poz. 2169.

Ustawa z dnia 24 sierpnia 2001 r. - Kodeks postępowania w sprawach o wykroczenia, tekst jednolity: Dz. U. z 2020 r. poz. 729.

Ustawa z dnia 20 lipca 2017 r. - Prawo wodne, tekst jednolity: Dz. U. z 2020 r. poz. 310 .

\section{Orzecznictwo}

Orzeczenie SN z dnia 21 kwietnia 2016 r., V KK 100/16, http:/ / www.sn.pl/ sites / orzecznictwo/orzeczenia3/v\%20kk\%20100-16.pdf [dostęp: 15.09.2019 r.].

\section{Literatura}

Banasik K., Penalizacja bezprawnego przekroczenia granicy państwowej, Studia Prawnicze. Rozprawy i Materiały 2017, nr 1.

Bezpieczeństwo na wodzie. Wywiad z insp. Markiem Walczakiem Dyrektorem Biura Prewencji i Ruchu Drogowego Komendy Głównej Policji, Kwartalnik Policyjny 2014, nr 3.

Jachimowicz M., Nowe zasady odpowiedzialności za nielegalne przekroczenie granicy $R P$, Prokuratura i Prawo 2006, nr 5.

Jankowski W., Komentarz do art. 49(a) Kodeksu wykroczeń, w: Kodeks wykroczeń. Komentarz, red. T.H. Grzegorczyk, 2013 [wyd. el. LEX].

Jurczak D., Wybrane zagadnienia zapewnienia bezpieczeństwa na morskim odcinku ochrony granicy państwowej, Edukacja Humanistyczna 2013, nr 2.

Kotowski W., Komentarz do art. 49(a) Kodeksu wykroczeń, w: Kodeks wykroczeń. Komentarz, Warszawa-Kraków 2009.

Merski J., Warecka J., Turystyka kwalifikowana, turystyka aktywna, Warszawa 2009.

Mozgawa M., Komentarz do art. 49(a) Kodeksu wykroczeń, w: Kodeks wykroczeń. Komentarz, red. M. Mozgawa, 2009 [wyd. el. LEX].

\section{Netografia}

http:/ / fakty.interia.pl/warminsko-mazurskie/news-bedzie-przejscie-graniczne-na-lynie,nId,1203970 [dostęp: 15.09.2019 r.].

http:/ / sepopol.wm.pl/364670,Odprawa-graniczna-kajakarzy-na-Lynie.html\# axzz4H2L6UZjF [dostęp: 15.09.2019 r.].

http:/ / turystyka.wp.pl/kat,1036541,title,Strefa-Schengen-za-granice-bez-dowodu,wid,18306480,wiadomosc.html?ticaid=1178c0 [dostęp: 15.09.2019 r.]. http:/ / www.government.by/ru/solutions/2658 [dostęp: 15.09.2019 r.]. 
http:/ / www.rp.pl/Obyczaje/308069971-Siedem-razy-wiecej-turystow-na-granicy-z-Bialorusia.html\#ap-1 [dostęp: 15.09.2019 r.].

http:/ / www.rp.pl/Promocja-turystyczna/310259898-Caly-Kanal-Augustowski-dostepny-bez-wizy.html\#ap-1 [dostęp: 15.09.2019 r.].

https://grodnovisafree.by/pl/operatorzy-turystyczni.html [dostęp: 15.09.2019 r.]. https://sepopol.pl/PL/drukuj/1000/202/XIX_Miedzynarodowy_splyw_ Lyna_-_Lawa_2019/wersja/ [dostęp: 15.09.2019 r.].

https://www.nik.gov.pl/aktualnosci/nik-o-dzialaniach-policji-wodnej-na-wodach-morskich-i-terenach-nadmorskich.html [dostęp: 15.09.2019 r.].

https://www.strazgraniczna.pl/pl/granica/granice-rp/1910,Granice-RP.html [dostęp: 15.09.2019 r.].

https://www.strazgraniczna.pl/pl/niezbednik-podroznego/przekraczanie-granic/2031,Przekraczanie-granic.html [dostęp: 15.09.2019 r.].

\section{Streszczenie}

W artykule dokonano analizy aktualnie obowiązujących przepisów prawa regulujących uprawianie turystyki wodnej na granicznych wodach śródlądowych i obszarach morskich Rzeczypospolitej Polskiej. Zwrócono uwagę na to, że podstawowym aktem normatywnym jest tzw. Kodeks graniczny Schengen, który nie przewiduje ograniczeń $\mathrm{w}$ zakresie przekraczania granicy z państwami strefy Schengen (tzn. Republiką Federalną Niemiec, Republiką Czeską, Republiką Słowacką oraz Republiką Litewską), co skutkuje tym, że uprawianie turystyki wodnej na wodach granicznych z tymi państwami może odbywać się swobodnie. Natomiast w przypadku państw, które nie znajdują się w strefie Schengen (Ukraina, Republika Białorusi i Federacja Rosyjska - Obwód Kaliningradzki) wymogi w zakresie uprawiania turystyki na wodach granicznych zawierają: rozporządzenie Ministra Spraw Wewnętrznych i Administracji z dnia 21 kwietnia 2008 r., dwustronne umowy międzypaństwowe oraz przepisy porządkowe właściwych miejscowo wojewodów. W kolejnej części tekstu dokonano analizy przepisów karnych odnoszących się do nielegalnego przekroczenia granicy państwowej Rzeczypospolitej lub niezastosowania się do zakazów zawartych w przepisach prawa. Podkreślono, że w zakresie przestrzegania przepisów prawa istotną rolę odgrywa Straż Graniczna oraz Policja, w szczególności - Policja wodna.

Słowa kluczowe: turystyka, turystyka wodna, śródlądowe wody graniczne, obszary morskie RP, przekroczenie granicy państwowej, kodeks graniczny Schengen 


\section{THE POSSIBILITY OF PRACTICING WATER TOURISM ON BORDER INLAND WATERS AND MARITIME AREAS OF THE REPUBLIC OF POLAND IN THE LIGHT OF LEGAL PROVISIONS}

\section{Sum mary}

The article analyses the current legal regulations concerning water tourism on the border of inland waters and maritime areas of the Republic of Poland. It has been pointed out that the basic normative act is the so-called Schengen Borders Code, which does not provide for limitations in the scope of crossing the border with the Schengen area countries (i.e. the Federal Republic of Germany, the Czech Republic, the Slovak Republic and the Republic of Lithuania); consequently, the water tourism in border waters with these countries may be practiced freely. However, in the case of countries which are not included in the Schengen area (Ukraine, the Republic of Belarus and the Russian Federation (the Kaliningrad District), the requirements concerning tourism on the border waters include: the regulation of the Minister of Internal Affairs and Administration of 21 April 2008, bilateral interstate agreements and regulations of the locally competent province governor. The second part of the article presents the analysis of criminal provisions relating to illegal crossing of the state border of the Republic of Poland and failure to comply with the prohibitions imposed by the law. It was stressed that the Border Guard and the Police, in particular the Water Police, play an important role in the compliance of the law.

Key words: tourism, water tourism, inland border waters, maritime areas of the Republic of Poland, crossing the state border, Schengen Borders Code

\section{ОГРАНИЧЕНИЯ ПРАКТИКИ ВОДНОГО ТУРИЗМА НА ВНУТРЕННИХ ПОГРАНИЧНЫХ ВОДАХ И МОРСКИХ ПРОСТРАНСТВАХ РЕСПУБЛИКИ ПОЛЬША В СВЕТЕ ПРАВОВЫХ НОРМ}

\section{Резюме}

В статье анализируются действующие в настоящее время правовые положения, регулирующие практику водного туризма на внутренних водах и морских пространствах Республики Польша. Было отмечено, что основным нормативным актом является так называемый Шенгенский кодекс о границах, который не предусматривает ограничений на пересечение границы со странами Шенгенской зоны (т.е. Федеративной Республикой Германия, Чешской Республикой, Словацкой Республикой и Литовской Республикой), что означает, что водный туризм на пограничных водах с этими 
странами может проходить свободно. Однако в случае стран, которые не входят в Шенгенскую зону (Украина, Республика Беларусь и Российская Федерация (Калининградская область), требования к практике туризма на пограничных водах включают: Постановление Министра внутренних дел и администрации от 21 апреля 2008 года, двусторонние соглашения и правила местных компетентных воевод. В следующей части статьи были проанализированы положения уголовного законодательства, касающиеся незаконного пересечения государственной границы Республики Польша или несоблюдения запретов, содержащихся в правовых нормах, и было подчеркнуто, что Пограничная служба и полиция играют важную роль в соблюдении закона, в частности - Водная полиция.

Ключевые слова: туризм, водный туризм, внутренние пограничные воды, морские пространства Республики Польша, пересечение государственной границы, Шенгенский кодекс о границах 